Japan. J. Med. Sci. Biol., 41, 1988.

\title{
SYMPOSIUM ON TOXINS
}

Proceedings of the 35th Symposium on Toxins held at Kan-onji, Kagawa, on July 8-10, 1988.

Director: Morihiro MATSUDA

Department of Tuberculosis Research I, Research Institute for

Microbial Diseases, Osaka University, Osaka

\section{CONTENTS}

A mutant strain of $B$. pertussis (79G6F2) which does not produce subunit S-1 of pertussis toxin: Masashi CHAZONO, Tsukasa NISHIHARA, Atsushi IMAIZUMI, Hiroko SATO and Yuji SATO

A new perchloric acid (PCA) treatment of human plasma for detection of endotoxin by endotoxin-specific chromogenic test: Katsuya INADA, Miyuki SUZUKI, Kazuhiko TAKAHASHI, Shigenori TANAKA, Hiroshi TAMURA, Tetsuo KOMURO and Masao YOSHIDA

Correlation between lipopolysaccharide and virulence plasmid of Salmonella: Kazuyoshi KAWAHARA, Takafumi HAMAOKA, Somay Y. MURAYAMA, Shoko SUZUKI, Masayuki NAKAMURA, Hirofumi DANBARA, Toshihiko ARAI and Nobuyuki TERAKADO.

Cloning of the $P$. aeruginosa cytotoxin gene by oligonucleotide probe: Tetsuya HAYASHI, Yoshifumi ITOH, Yoshiyuki KAMIO and YoshiroTERAWAKI.

Analysis of the thermostable direct hemolysin-related gene ( $t r h$ gene) of Kanagawa phenomenon-negative Vibrio parahaemolyticus isolated from diarrheal patients: Mitsuaki NISHIBUCHI, Tooru TANIGUCHI, Hiromasa SHIRAI, Vanna KHAEOMANEE-IAM. Tadashi MISAWA, Takeshi HONDA, Yoshifumi TAKEDA and Toshio MIWATANI

Studies on streptococcal erythrogenic toxin type a -- production in the synthetic medium and purification: Yukio KAMEZAWA and TakakoNAKAHARA

Detection of a precursor form of Vibrio metschnikovii cytolysin: Masami MIYAKE, Takeshi HONDA and Toshio MIWATANI 
A protease in the venom of king cobra (Ophiophagus hannah): purification, characterization and substrate specificity on oxidized insulin B-chain: Yoshio YAMAKAWA and Tamotsu OMORI-SATOH.

Isolation and some properties of the subunits of VT2 from enterohemorrhagic Escherichia coli 0157:H7: Hideaki ITO, Takashi YUTSUDO, Toshiya HIRAYAMA and Yoshifumi TAKEDA

A new TDH-related hemolysin produced by a clinical isolate of

Kanagawa phenomenon-negative Vibrio parahaemolyticus:

Takeshi HONDA, Yuxin NI, Shun-ichi HONDA, Kenji

SHIMOIRISA and Toshio MIWATANI.

Amino acid sequence of a Vibrio hollisae hemolysin that relates to the thermostable direct hemolysin of Vibrio parahaemolyticus:

Myonsun YOH, Takeshi HONDA, Toshio MIWATANI, Susumu TSUNASAWA and Fumio SAKIYAMA.

Primary structure of hemorrhagic principles, HR2a, in the venom of Trimeresurus flavoviridis: Toshiyuki MIYATA, Yasushi OZEKI, Fuminori TOKUNAGA, Sadaaki IWANAGA and Tamotsu SATOH-OHMORI.

Substitution of asparagine residue at the $\mathrm{C}$ terminus of Escheichia coli heat-stable enterotoxin: Jun YUKITAKE, Keinosuke OKAMOTO, Kyoko OKAMOTO and Akio MIYAMA.

An immunochemical study on O-antigenic (endotoxic) lipopolysaccharides of $\mathrm{O} 1$ Vibrio cholerae: Kazuhito HISATSUNE, Masahiro HAYASHI, Yuji HAISHIMA and Seiichi KONDO.

Analysis of lipid A epitopes by various monoclonal antibodies: Satoru ARATA, Jun-ichi MASHIMO, Mari UENO and Nobuhiko KASAI.

Lipopolysaccharides from proteus strains used in Weil-felix reaction: Ken-ichi AMANO, Sakae MIZUSHIRI, Kazue FUKUSHI and Mitsuru WATANABE.

Effect of structure and binding positions of acyl substituents in subunit analogues of lipid A on their biological activities: Motohiro MATSUURA, Hiroaki TAKIMOTO, Mitsunobu NAKATSUKA, J. Yuzuru HOMMA, Satoru IKEDA, Yoshio KUMAZAWA, Chiaki NISHIMURA, Akihiro YAMAMOTO, Makoto KISO and Akira HASEGAWA 
Detection of high- and low-affinity binding sites of cholesterol on sheep and human erythrocyte membranes with modified $\theta$-toxin of Clostridium perfringens as a probe: Yoshiko OHNOIWASHITA, Machiko IWAMOTO, Ken-ichiro MITSUI and Susumu ANDO

Antigenic structure and binding kinetics of Clostridium botulinum type B neurotoxin: Jun OGASAWARA, Shunji KOZAKI, Yoichi KAMATA and Genji SAKAGUCHI.

Inhibitory effects of lipopolysaccharides on murine B cell lines, CYG34 and CYG101, and identification of Re LPS-binding protein on cell membrane of murine lymphoid cell lines: Teruo KIRIKAE, Fumiko HONDA-KIRIKAE, Katsuya INADA, Masao YOSHIDA,Kazuhito HISATSUNE, Yuji HAIJIMA and Shinichi NISHIKAWA

Identification of receptors of Escherichia coli heat-stable enterotoxin on cell membrane of rat intestine by photoaffinity labeling: Toshiya HIRAYAMA, Yuichi OKU, Futami MATSUDA, Naomi NAKABAYASHI, Keiko MATSUMOTO, Yoshifumi TAKEDA, Naohito IWATA, Saburo AIMOTO and Yasutsugu SHIMONISHI.

Features of ionic currents of smooth muscle cell membranes and actions of some toxins on their ionic channels: Hirosi KURIYAMA, Kenji KITAMURA and Kenji SAKAI

Structure and function relationship of tetanus toxin: blockade of synaptic transmission by fragment [A-B], the N-terminal fragment of tetanus toxin: Kunihiro OZUTSUMI, Kohsi TAKANO, Andreas GREMMELT, Nakaba SUGIMOTO and Morihiro MATSUDA

An attempt to introduce encephalopathy with pertussis toxin in «ace. Hiroko SATO and Yuji SATO.

Effects of staphylococcal exotoxin, toxic shock syndrome toxin-1 on $i_{\text {.. }}$ vitro antibody responses of mice: Xiao-jie YAN, Shinji SAITO, Takehiko UCHIYAMA, Hiroshi FUJIKAWA and Hideo IGARASHI 
Mechanisms of macrophage activation by bacterial lipopolysaccharides: defective site on LPS-unresponsive $\mathrm{C} 3 \mathrm{H} / \mathrm{HeJ}$ peritoneal macrophages: Yasuhiko TERADA, Hiroto SHINOMIYA and Masayasu NAKANO.

Effect of Clostridium perfringens $\varepsilon$-toxin on the isolated rat intestine: Masahiro NAGAHAMA, Toshihiro TAKAHASHI, Keiko KOBAYASHI and Jun SAKURAI.

Action of Bordetella heat-labile toxin on vascular smooth muscle cells and its binding to the cells: Masaaki NAGAI, Masahiko ENDOH and Yasukiyo NAKASE.

Inhibition of the release of various neurotransmitters from fetal rat brain cells in dissociated culture by botulinum neurotoxins: Naomi YASUNO, Ichiro MATSUOKA, Bunei SYUTO, Kohji MIRIISHI and Kenzo KURIHARA

Platelet aggregation caused by Clostridium perfringens alpha toxin: Yoshio FUJI, Sadayuki OCHI, Keiko KOBAYASHI and Jun SAKURAI.

Some properties of hog brain actin ADP-ribosylated with component I of botulinum $\mathrm{C} 2$ toxin: Iwao OHISHI and Yoshiharu MORIKAWA

Studies on the mechanism of membrane-damaging action of the enterotoxin of type A Clostridium perfringens on artificial lipid bilayer membranes: Nakaba SUGIMOTO, Kunihiro OZUTSUMI, Shigeko HARADA, LEI Dian-Liang, LIU Chang-Nuan and Morihiro MATSUDA 
Japan. J. Med. Sci. Biol., 41, 1988.

\title{
A MUTANT STRAIN OF B.PERTUSSIS (79G6F2) WHICH DOES NOT PRODUCE SUBUNIT S-1 OF PERTUSSIS TOXIN
}

\author{
Masashi CHAZONO, Tsukasa NISHIHARA1, Atsushi IMAIZUMI2, \\ Hiroko $\mathrm{SATO}^{3}$ and Yuji $\mathrm{SATO}^{3}$
}

Kanonji Institute, the Research Foundation for Microbiological Diseases of Osaka University, 2-9-41, Yahata-cho, Kanonji-shi, Kagawa, 768, 1The Chemo-SeroTherapeutic Research Institute, 668 Okubo, Shimizu, Kumamoto-shi, 2Teijin Institute for Biomedical Research, Asahigaoka 4-3-2, Hino-shi, Tokyo 191 and 3 National Institute of Health, 2-10-35, Kamiosaki, Shinagawa-ku, Tokyo 141

A whole cell pertussis vaccine is known to accompany the strong side effect, so it has been desired to improve it. In Japan a new type pertussis vaccine, consisting mainly of Pertussis Toxin (PT) and Filamentous Hemagglutinin (FHA) detoxified with formalin, has been successfully developed and it is widely used for vaccination since 1981. Since then, this improved vaccine (Acellular Pertussis Vaccine) has been inoculated in more than 30 million doses to children and in fact the side effects have been decreased.

Recently, information of undesirable reversion of this toxoid PT to original activities to a detectable extent has been gradually accumulated. Moreover, recent sequencing analysis of DNA coding for PT revealed that subunit one of PT (S-1) has not any lysine residue in the molecule. This finding suggests that the detoxification of S-1, which catalyzes ADP-ribosylation by PT, through Sciff's base formation by formalin treatment might be a matter to be considered.

In this study, to solve these problems, a mutant producing nontoxic protein of $\mathrm{PT}$ which still can induce the protective antibody was intended for the vaccine production. A mutant, Tohama $79 \mathrm{G} 6 \mathrm{~F} 2$, was selected as a strain which phenotypically lacks CHO-cell-clustering activity, among about 12,000 colonies gained after NTG treatment of parent $B$. pertussis Tohama phase I. Relevant properties of 79G6F2 are summarized as follows:

1. Serotype of the mutant Tohama 79G6F2. It was demonstrated that the strain had the same antigenic factors (Serotypes 1,2 and 4) as parent pertussis Tohama phase I.

2. Toxicity of the strain. Virulence of the strain was tested by mouse intracerebral challenge method. Mouse HS (Histamine-sensitizing), 
Japan. J. Med. Sci. Biol., 41, 1988.

mouse LP (Leukocyte-promoting), mouse IA (Islet-activating), rabbit vascular permeability stimulating and $\mathrm{CHO}$ cell-clustering activities were measured to determine the biological activities of PT. According to these tests, it was confirmed that the strain has no virulence and no biological activities of PT.

3. Detection of produced nontoxic protein. Detection of nontoxic protein produced in culture supernatant was confirmed by ELISA using anti-PT, anti-S- 1 and anti-S-2,3 antibodies.

4. Analysis of nontoxic protein. S-1-deficient PT produced by the mutant $79 \mathrm{G} 6 \mathrm{~F} 2$ was confirmed by the immunodiffusion test, SDS-PAGE and Western blotting method.

5. Neutralization of the biological activities of PT by the serum against the nontoxic protein. The antibodies against the nontoxic protein neutralized such PT activities as LP, HS, IA and CHO cell-clustering activities.

6. Protective effects of the nontoxic protein. By intracerebral challenge of the mice with virulent $B$. pertussis $18-323$, the nontoxic protein showed the protective effects to the same extent as did parent PT.

From the results of these tests, it was concluded that it would be appropriate to use this mutant Tohama 79G6F2 strain for the production of novel Acellular Pertussis Component Vaccine. 
Japan. J. Med. Sci. Biol., 41, 1988.

\title{
A NEW PERCHLORIC ACID (PCA) TREATMENT OF HUMAN PLASMA FOR DETECTION OF ENDOTOXIN BY ENDOTOXIN-SPECIFIC CHROMOGENIC TEST
}

\author{
Katsuya INADA, Miyuki SUZUKI, Kazuhiko TAKAHASHI, \\ Shigenori TANAKA1, Hiroshi TAMURA1, Tetsuo KOMURO2 \\ and Masao YOSHIDA
}

Department of Bacteriology, School of Medicine, Iwate Medical University, Morioka 020, 1 Tokyo Research Institute, Seikagaku Kogyo, Ltd., Higashiyamato, Tokyo 189, and 2 National Institute of Hygiene (Osaka), Osaka 540

The endotoxin level of human plasma has been determined by an endotoxinspecific chromogenic test (Endospecy, Seikagaku Kogyo) (1). The test reagent was composed of recombined coagulation enzymes of amoebocyte lysate from Tachyphleus tridentatus (Japanese horseshoe crab) and synthetic chromogenic substrate; moreover, factor $\mathrm{G}$, sensitive to $\beta$-D-glucan, was depleted to qualify the endotoxin-specificity. The perchloric acid (PCA) treatment of human plasma has been used to remove the factors interfering with endotoxin measurement (2). In this method, PCA is added to plasma and the precipitate is discarded after centrifugation. The supernatant is employed for detection of endotoxin. We found, however, a large amount of Limulus (Endospecy) activity in the precipitate of PCA-treatment both of patient plasma with sepsis and of LPS-spiked plasma. The endotoxin activities of the precipitates, corresponding to that of the Limulus test, were found by the rabbit pyrogen test and lethality test in galactosaminesensitized mice. Thus, it is rational to determine the endotoxin level of the supernatant and the precipitate. Therefore, we developed the new PCA-treatment by which endotoxin in both the precipitate and supernatant can be determined. Interfering factors contained in plasma were virtually removed by the new PCAtreatment. The new PCA-treatment of plasma allowed determination of about 10 times higher endotoxin content than that of the original PCA-treatment. In liver diseases, the new PCA-treatment was found to be useful for determination of endogenous endotoxemia.

\section{REFERENCES}

1. Obayashi, T., Tamura, H., Tanaka, S., Ohki, M., Takahashi, S., Arai, M., Masuda, M. and Kawai, T. (1985): Clin. Chim. Acta, 149, 55-65.

2. Obayashi, T. (1984): J. Lab. Clin. Med., 104, 321-330. 
Japan. J. Med. Sci. Biol., 41, 1988.

\title{
CORRELATION BETWEEN LIPOPOLYSACCHARIDE AND VIRULENCE PLASMID OF SALMONELLA
}

\author{
Kazuyoshi KAWAHARA, Takafumi HAMAOKA1, Somay Y. MURAYAMA2, \\ Shoko SUZUKI33, Masayuki NAKAMURA33, Hirofumi DANBARA, \\ Toshihiko ARAI2 and Nobuyuki TERAKADO1
}

Department of Bacteriology, The Kitasato Institute, Minato-ku, Tokyo 108, 1National Institute of Animal Health, Tsukuba, Ibaraki 305, 2Department of Microbiology, Meiji College of Pharmacy, Setagaya-ku, Tokyo 154, and 3National Veterinary Assay Laboratory, Kokubunji, Tokyo 185

Salmonella infection has been studied for a long time, but little is known on the molecular mechanisms of infection. W and other groups reported recently that most of Salmonella strains have serotype-specific plasmids and that those plasmids have relation with the virulence of the bacteria to mice (1-3). To investigate the function and gene products of the serotype-specific plasmid (virulence plasmid), we constructed plasmid-cured and -reintroduced strains of $S$. dublin, S. enteritidis, $S$. typhimurium and S. choleraesuis, whose virulence plasmids had molecular sizes of $50 \mathrm{Mdal}, 36 \mathrm{Mdal}, 60 \mathrm{Mdal}$ and $30 \mathrm{Mdal}(50 \mathrm{~kb})$, respectively.

In this study, lipopolysaccharide of those constructed strains was compared with that of corresponding parent strains since lipopolysaccharide is one of the most important virulence factors of Salmonella. Lipopolysaccharide was extracted by the $45 \%$ hot-phenol method, purified by ultracentrifugation, and submitted to chemical analysis. It was revealed that the amount of sugars in the O-specific chain was remarkably decreased to only one repeating unit in the lipopolysaccharide of $50 \mathrm{Mdal}$ plasmid-cured strain of S. dublin and it was restored by reintroduction of the plasmid. In contrast, no difference was detected among lipopolysaccharides of parent, plasmid-cured and -reintroduced strains of $S$. enteritidis, S. typhimurium and S. choleraesuis. Lipopolysaccharide of those Salmonella strains was also analyzed by SDS-polyacrylamide gel electrophoresis. Lipopolysaccharide of a cured strain of $S$. dublin showed no ladder at the region of high molecular weight, indicating that it had very short or no $\mathrm{O}$-specific chain.

From these results it is concluded that the plasmid-cured strain of $S$. dublin has semirough lipopolysaccharide and assumed that virulence plasmid of S. dublin encodes the factors affecting polymerization of the O-specific chain of lipopolysaccharide. 
Japan. J. Med. Sci. Biol., 41, 1988.

\section{REFERENCES}

1. Terakado, N., Sekizaki, T., Hashimoto, K. and Naitou, S. (1983): Infect. Immun., 41, 443-444.

2. Nakamura, M., Sato, S., Ohya, T., Suzuki, S. and Ikeda, S. (1985): Infect. Immun., 47, 831-833.

3. Kawahara, K., Haraguchi, Y., Tsuchimoto, M., Terakado, N. and Danbara, H. (1988): Microbial Pathogen., 4, 155-163.

\section{CLONING OF THE P. AERUGINOSA CY'TOTOXIN GENE BY OLIGONUCLEOTIDE PROBE}

Tetsuya HAYASHI, Yoshifumi ITOH, Yoshiyuki KAMIO and Yoshiro TERAWAKI

Department of Bacteriology, Shinshu University School of Medicine, Matsumotoshi, Nagano 390

Pseudomonas aeruginosa is the most important opportunistic pathogen. Several components related to its virulence have been identified and characterized (1). Cytotoxin, which was originally designated leucocidin by Sharmann (2) and later renamed cytotoxin by Lutz (3), is also thought to be one of the virulence factors because of its cytotoxic action against most eukaryotic cells, especially against leukocytes. This toxin is uniquely produced as a cell-associated inactive precursor not secreted into culture medium and converted to an active cytotoxin by proteolytic enzymes during the bacterial autolysis (2). Nevertheless, very little information is available about the precursor and the process of its activation. In this study, we cloned the cytotoxin gene (ctx gene) and determined its nucleotide sequence to know the primary structure of the cytotoxin.

We already purified a $29 \mathrm{KD}$ active cytotoxin by treating the crude extract of $P$. aeruginosa strain 158 with trypsin (to be published). The $\mathrm{N}$-terminal amino acid sequence of the purified cytotoxin was determined and 17 mer oligonucleotides probes corresponding to the sequence of the first six amino acids were synthesized. By the plaque hybridization method, ctx gene was screened from a 
Japan. J. Med. Sci. Biol., 41, 1988.

genomic library of $P$. aeruginosa strain 158 constructed by inserting $10-20 \mathrm{~Kb}$ Sau $3 \mathrm{~A}$ fragments into $\mathrm{Bam} \mathrm{HI}$ sites of EMBL-3 cloning vector, and several positive clones were obtained. DNAs from positive clones were digested with several restriction enzymes and analyzed by Southern blot hybridization. ctx gene was found to exist in the middle of a $5.6 \mathrm{~Kb}$ Sal I fragment, which was subcloned into pUC 18. Then the complete nucleotide sequence of $c t x$ gene was determined by the dideoxy chain method. It was revealed that $c t x$ gene encoded $31 \mathrm{KD}$ polypeptide composed of 286 amino acids. The $\mathrm{N}$-terminal amino acid sequence was the same as that obtained from protein analysis of the purified active cytotoxin. No leader peptide existed. This suggests that an inactive precursor is located in cytoplasm and that proteolytic cleavage at the $\mathrm{N}$-terminal region is not involved in the process of activation.

When whole $c t x$ gene along with 5' and 3' flanking regions was subcloned in a high-copy vector pUC18 and transformed into $E$. coli, cytotoxin was not detected by either Western immunoblotting or the assay for leukocytotoxic activity. Gene product was detected, however, when a lac Z-ctx fusion gene was constructed and expressed in E. coli under the control of lac promoter.

\section{REFERENCES}

1. Lory, S. and Tai, P. C. (1985): Corr. Top. Microbiol. Immunol., 188, 53-69.

2. Scharmann, W. (1976): J. Gen. Microbiol., 93, 283-291.

3. Lutz, F. (1979): Toxicon, 17, 467-475. 
Japan. J. Med. Sci. Biol., 41, 1988.

ANALYSIS OF THE THERMOSTABLE DIRECT HEMOLYSIN-RELATED GENE (trh GENE) OF KANAGAWA PHENOMENON-NEGATIVE VIBRIO PARAHAEMOLYTICUS ISOLATED FROM DIARRHEAL PATIENTS

\author{
Mitsuaki NISHIBUCHI, Tooru TANIGUCHI1, Hiromasa SHIRAI, \\ Vanna KHAEOMANEE-IAM1, Tadashi MISAWA1, Takeshi HONDA1, \\ Yoshifumi TAKEDA and Toshio MIWATANI1
}

Department of Microbiology, Faculty of Medicine, Kyoto University, Konoe-cho, Yoshida, Sakyo-ku, Kyoto 606 and 1Research Institute for Microbial Diseases, Osaka University, 3-1 Yamada-oka, Suita, Osaka 565

Kanagawa phenomenon-negative Vibrio parahaemolyticus strains isolated from patients of traveller's diarrhea returning from Moldives produced a hemolysin related to the thermostable direct hemolysin $(1,2)$.

The gene encoding the hemolysin (trh gene) was cloned by using the DNA probe for the thermostable direct hemolysin gene ( $t d h$ gene) (3) under reduced stringency and the gene was analyzed. The nucleotide sequence of the trh gene was determined and compared with those of the $t d h$ gene. Like the $t d h$ gene, the trh gene encoded a hemolysin composed of 165 amino acid residues. The trh gene had $68-69 \%$ nucleotide sequence homology (62-63\% protein sequence homology) with the $t d h$ gene.

The DNA colony hybridization tests of $V$. parahaemolyticus isolates with two DNA probes for examining the $t r h$ gene and the surrounding sequences, $2.3 \mathrm{~kb} \mathrm{Ava}$ I fragment containing the gene and a $334 \mathrm{bp}$ gene-specific probe derived from the internal portion of the gene, were performed. The results suggest that the trh gene may be mobile. The trh gene was rarely detected in the environmental isolates.

\title{
REFERENCES
}

1. Honda, S., Goto, I., Minematsu, I., Ikeda, N., Asano, N., Ishibashi, M., Kinoshita, Y., Nishibuchi, M., Honda, T. and Miwatani, T. (1987): Lancet, $i$, 331-332.

2. Honda, T., Ni, Y. and Miwatani, T. (1988): Infect. Immun., 56, 961-965.

3. Nishibuchi, M., Ishibashi, M., Takeda, Y. and Kaper, J. B. (1985): Infect. Immun., 49, 481-486. 
Japan. J. Med. Sci. Biol., 41, 1988.

STUDIES ON STREPTOCOCCAL ERYTHROGENIC TOXIN TYPE A -PRODUCTION IN THE SYNTHETIC MEDIUM AND PURIFICATION

Yukio KAMEZAWA and Takako NAKAHARA

Saitama College of Health, Kami-Ohkubo, Urawa, Saitama 338

Streptococcal erythrogenic toxin type A has various biological activities (1). Many investigators have reported purification and characterization of the toxin, but their results differ in many respects from one to another. Characterization of the toxin has not been efficient because of the difficulties in purification.

When a synthetic medium (NCTC-135) was used for cultivation of NY-5 strain, the amount of the toxin produced was almost the same as that found in the dialyzed pepton medium (TP). Concentrate of this culture filtrate was fractioned by chromatofocusing ( $\mathrm{pH} 6.5-4.0$ ). The toxin protein was eluted at $\mathrm{pH} 5.4$ as the main peak. The separation was pretty clear, but the peak was still contaminated by other proteins. After gel filtration of this fraction through Sephacryl S-200, the toxin protein was eluted as a single peak, which formed a single band of $\mathrm{Mr} 28000$ on SDS-PAGE and had pI 5.2 on agarose IEF ( $\mathrm{pH}$ 6.5-4.0). Thus, using the synthetic medium, succeeded to simplify the procedures of purification of the toxin from culture filtrate. The results of amino acid analysis of this protein were in accordance with those by Ferretti et al. (3), who determined the nucleotide sequence of erythrogenic toxin type A gene.

Furthermore, we attempted to improve the chemically defined medium reported by Kessler et al (2). Our modified medium (CDM-2) did not support growth of NY-5 strain, while T1 strain grew well and produced the toxin in it. Production of the toxin by T1 strain was higher in CDM-2 than in TP. Contaminating proteins were far less in amount. We expect to purify the toxin of $\mathrm{T} 1$ strain to a homogeneous state by use of CDM-2.

We have found various effects of supplements of the synthetic medium on the growth and the toxin production of the bacteria. Detailed aspects of the effects are now under investigation.

\section{REFERENCES}

1. Kim, Y. B. and Watson, D. W. (1970): J. Exptl. Med., 131, 611-628.

2. van de Rijn, I. and Kessler, R. E. (1980): Infect. Immun., 27, 444-448.

3. Weeks, C. R. and Ferretti, J. J. (1986): Infect. Immun., 52, 144-150. 
Japan. J. Med. Sci. Biol., 41, 1988.

\title{
DETECTION OF A PRECURSOR FORM OF VIBRIO METSCHNIKOVII CYTOLYSIN
}

\author{
Masami MIYAKE, Takeshi HONDA and Toshio MIWATANI
}

Department of Bacteriology and Serology, Research Institute for Microbial Diseases, Osaka University, 3-1 Yamadaoka, Suita, Osaka 565

Cytolysins or hemolysins interest many researchers in finding how the toxins lyse erythrocytes, as it has not been clearly understood. We purified a cytolysin produced by Vibrio metschnikovii and analyzed the mechanism of the cytolysininduced hemolysis. During these investigations, we found that a precursor form of this cytolysin was extracellularly produced earlier during cultivation. In the present study, we characterized this precursor cytolysin in crude materials and tried to purify it.

The supernatant of rotary culture of Vibrio metschnikovii was electrophoresed in the presence or absence of SDS and transferred to nitrocellulose paper. The cytolysin was detected on the paper by immunostaining with anti-cytolysin rabbit antibody and peroxidase-conjugated anti-rabbit IgG goat antibody.

Two anti-cytolysin antibody-reactive proteins were detected in culture supernatant of the bacteria. One, detected in 3 to 6 - $\mathrm{hr}$ culture, having a molecular weight of about 70,000 seemed to be the precursor cytolysin (p-CTL). The other, having a molecular weight of 50,000 , detected in 4 - $\mathrm{hr}$ or longer culture seemed to be the mature cytolysin (m-CTL). In the filtrate of $6-\mathrm{hr}$ culture supernatant (containing both p- and m-CTL), p-CTL gradually disappeared on incubation of the filtrate at $37 \mathrm{C}$ and the amount of $\mathrm{m}$-CTL increased. On the other hand, in the filtrate of 4-hr culture supernatant (containing p-CTL but no m-CTL), neither disappearance of p-CTL nor emergence of m-CTL was observed upon incubation. These findings indicate the presence of precursor cytolysin, which is resistant to the incubation at $37 \mathrm{C}$ and that the active conversion system of p-CTL to m-CTL exists in 6-hr culture supernatant.

Attempts to purify p-CTL were also made. A crude p-CTL preparation was obtained by ammonium sulfate precipitation. The precipitate was resuspended in distilled water. Ammonium sulfate was removed by gel filtration on Sephadex G25. This crude material was subjected to gel filtration on a Sephadex G-100 
Japan. J. Med. Sci. Biol., 41, 1988.

column equilibrated with a buffer containing urea; $\mathrm{p}$-CTL was separated from nC'TL by this chromatography, but many other proteins were still present. Further purification of $\mathrm{p}$-CTL is now in progress.

\title{
A PROTEASE IN THE VENOM OF KING COBRA (OPHIOPHAGUS HANNAH): PURIFICATION, CHARACTERIZATION AND SUBSTRATE SPECIFICITY ON OXIDIZED INSULIN B-CHAIN
}

\author{
Yoshio YAMAKAWA and Tamotsu OMORI-SATOH
}

Department of Applied Immunology, National Institute of Health, Kamiosaki 2-1035, Shinagawa-ku, Tokyo 141

A protease in the venom of Ophiophagus hannah (King cobra) has been purified to a homogeneous state by successive chromatography on Sephadex G-100 superfine, DEAE-cellulose, hydroxyapatite and CM-polyvinylalchol copolymer columns. The molecular weight determined by SDS-PAGE was approx. 70,000. The purified enzyme possessed a specific activity approx. one-twenty-fifth that of crystalline trypsin, whereas it had no hemorrhagic activity. The substrate specificity was determined on oxidized insulin B-chain as a substrate; the enzyme cleaved the $\mathrm{Asn}_{3}$-Gln 4 , Gln 4 -His5, His 10 -Leu11, Ala 14 -Leu 15 and Tyr 16 -Leu 17 positions. The sites cleaved by the protease were compared with those with proteases from other snake venoms. 
Japan. J. Med. Sci. Biol., 41, 1988.

ISOLATION AND SOME PROPERTIES OF THE SUBUNITS OF VT2 FROM ENTEROHEMORRHAGIC ESCHERICHIA COLI 0157:H7

Hideaki ITO, Takashi YUTSUDO, Toshiya HIRAYAMA and Yoshifumi TAKEDA

Department of Bacterial Infection, The Institute of Medical Science, The University of Tokyo, 4-6-1 Shirokanedai, Minato-ku, Tokyo 108

Escherichia coli 0157:H7 produces two types of Vero toxins (VT1 and VT2). VT1 is a molecule with the same properties as Shiga toxin (1), while VT2 has immunological and physicochemical properties different from those of VT1 or Shiga toxin. However, they have similar biological activities (2) such as Vero cell cytotoxicity and mice lethality. Moreover, the modes of action of VT1 and VT2 were shown to be identical (3). These results suggest some structural similarity between VT1 and VT2.

In this study, we examined some properties of the subunits of VT2 and the possibility of obtaining biologically active hybrid toxins of VT1 and VT2. The A and $B$ subunits of VT2 were separated by HPLC. The pI values of the A and B subunits of VT2 were 8.1 and 4.1, respectively. Since the pI values of the A and B subunits of Shiga toxin or VT1 were 8.2 and 5.8, respectively (4), the A subunit and especially the B subunit of VT1 seem to contain more basic amino acids than respective subunits of VT2. Biologically active hybrid toxins were obtained with combinations of the A subunit of VT1 and B subunit of VT2 and the A subunit of VT2 and B subunit of VT1.

\section{REFERENCES}

1. Noda, M., Yutsudo, T., Nakabayashi, N., Hirayama, T. and Takeda, Y. (1987): Microb. Pathog., 2, 339-349.

2. Yutsudo, T., Nakabayashi, N., Hirayama, T. and Takeda, Y. (1987): Microb. Pathog., 3, 21-30.

3. Endo, Y., Tsurugi, K., Yutsudo, T., Takeda, T., Ogasawara, T. and Igarashi, K. (1988): Eur. J. Biochem., 171, 45-50.

4. Yutsudo, T., Honda, T., Miwatani, T. and Takeda, Y. (1987): Microbiol. Immunol., 31, 189-197. 
Japan. J. Med. Sci. Biol., 41, 1988.

\section{A NEW TDH-RELATED HEMOLYSIN PRODUCED BY A CLINICAL ISOLATE OF KANAGAWA PHENOMENON-NEGATIVE VIBRIO PARAHAEMOLYTICUS}

Takeshi HONDA, Yuxin NI, Shun-ichi HONDA, Kenji SHIMOIRISA and Toshio MIWATANI

Research Institute for Microbial Diseases, Osaka University, Yamadaoka, Suita, Osaka 565

Thermostable direct hemolysin (VP-TDH) is considered to be a toxin closely related to the pathogenesis of $V$. parahaemolyticus. There are, however, several reports on cases of Kanagawa phenomenon-negative (Vp-TDH nonproducing) $V$. parahaemolyticus infection.

We recently found an outbreak of gastroenteritis due to a Kanagawa phenomenon-negative $V$. parahaemolyticus (1). In the present study, we investigated possible production of toxin(s) by the Kanagawa phenomenonnegative clinical $V$. parahaemolyticus isolate.

Although the strain was judged to be Kanagawa phenomenon-negative by various conventional tests, it produced a new hemolysin (named Vp-TRH, for VpTDH-related hemolysin) that was related to the Vp-TDH (2). Vp-TRH was purified by ammonium sulfate fractionation and successive column chromatography on DEAE-cellulose, hydroxyapatite and Mono Q. The molecular weight of Vp-TRH was estimated at 48,000 by Sephadex G-100 gel filtration and that of the subunit at 23,000 by SDS-slab gel electrophoresis. Thus, like Vp-TDH, Vp-TRH seems to be composed of two subunits. Vp-TRH showed lytic activities different from those of Vp-TDH on erythrocytes from various animals, especially those from calves, chickens, and sheep. The hemolytic activity of Vp-TRH was labile on heat treatment at $60 \mathrm{C}$ for $10 \mathrm{~min}$, unlike that of $\mathrm{Vp}-\mathrm{TDH}$. Immunological similarities but not the identities between Vp-TRH and Vp-TDH were demonstrated.

Thus, we conclude that this clinical isolate of Kanagawa phenomenonnegative $V$. parahaemolyticus produces a new type of hemolysin that is similar, but not identical, to ordinary Vp-TDH. Since not only Kanagawa phenomenonpositive but also Kanagawa-negative clinical isolates of $V$. parahaemolyticus produce Vp-TDH or Vp-TRH, both hemolysins may be important in the pathogenesis of $V$. parahaemolyticus. 
Japan. J. Med. Sci. Biol., 41, 1988.

\section{REFERENCES}

1. Honda, S., Goto, I., Minematsu, I., Ikeda, N., Asano, N., Ishibashi, M., Kinoshita, Y., Nishibuchi, M., Honda, T. and Miwatani, T. (1987): Lancet, i, 331-332.

2. Honda, T., Ni, Y. and Miwatani, T. (1988): Infect. Immun., 56, 961-965.

\section{AMINO ACID SEQUENCE OF A VIBRIO HOLLISAE HEMOLYSIN THAT RELATES TO THE THERMOSTABLE DIRECT HEMOLYSIN OF VIBRIO PARAHAEMOLYTICUS}

Myonsun YOH, Takeshi HONDA, Toshio MIWATANI, Susumu TSUNASAWA 1 and Fumio SAKIYAMA 1

Research Institute for Microbial Diseases, and 1Institute for Protein Research, Osaka University, Suita, Osaka 565

A halophilic vibrio, Vibrio hollisae, is considered to cause enteric disease. It was isolated from stool cultures of cases in which no other enteric pathogens were identified. Patients had usually diarrhea and abdominal pain and frequently vomiting and bloody diarrhea resembling those seen in cases associated with Vibrio cholerae non-O1.

We demonstrated that Vibrio hollisae produces a hemolysin (Vh-rTDH) which relates to thermostable direct hemolysin of Vibrio parahaemolyticus (VpTDH). We purified Vh-rTDH to the homogeneity and compared its characteristics with those of Vp-TDH (1). Though both hemolysins are primarily similar structurally, biologically and immunologically, most interesting difference is heat stability; Vp-TDH is heat-stable, whereas Vh-rTDH is heat-labile.

To elucidate the relationships between their characteristics and molecular structure, we tried to clarify the amino acid sequence of Vh-rTDH. The complete amino acid sequence of Vh-rTDH was determined by sequencing peptides obtained by Achromobacter protease I digestion. Like Vp-TDH, the subunit of Vh-rTDH consisted of 165 amino acid residues with the sole disulfide bond between Cys 151 
Japan. J. Med. Sci. Biol., 41, 1988.

and Cys 161. When the total amino acid sequence of Vh-rTDH was compared to that of Vp-TDH, 23 amino acid residues were different. Predicted hydropathy of Vh-rTDH from amino acid sequence is similar to that of Vp-TDH. Substitution of 14 amino acid residues resulted in change of charge.

\section{REFERENCE}

1. Yoh, M., Honda, T. and Miwatani, T. (1986): Can. J. Microbiol., 32, 632-636.

\section{PRIMARY STRUCTURE OF HEMORRHAGIC PRINCIPLES, HR2a, IN THE VENOM OF TRIMERESURUS FLAVOVIRIDIS}

Toshiyuki MIYATA, Yasushi OZEKI, Fuminori TOKUNAGA, Sadaaki IWANAGA and Tamotsu SATOH-OHMORI1

Department of Biology, Faculty of Science, Kyushu University, 33, Fukuoka 812, and 1Department of Applied Immunology, National Institute of Health, Kamiosaki, Shinagawa-ku, Tokyo 141

The entire amino acid sequence of HR2a (1), one of the hemorrhagic proteins derived from $\mathrm{Habu}$ (Trimeresurus flavoviridis) venoms, was determined by characterization of the $\mathrm{CNBr}$ fragments and the lysylendopeptidase peptides of the molecule. HR2a was a basic protein consisting of a single polypeptide chain of 202 amino acid residues and with a calculated molecular weight of 23,039 . The aminoterminal residue was pyroglutamic acid. We have located all the disulfide linkages in the HR2a molecule. The amino acid compositions and sequence analyses of three cystine-containing peptides established disulfide linkages Cys-159-Cys-181, Cys-161-Cys-164, and Cys-118-Cys-197. HR2a showed local homology to thermolysin, neutral protease, Serratia protease, collagenase, stromelysin, transin, and enkephalinase, in the sequence adjacent to the potential zinc-binding sites.

\section{REFERENCE}

1. Takahashi, T. and Ohsaka, A. (1970): Biochem. Biophys. Acta, 207, 65-75. 
Japan. J. Med. Sci. Biol., 41, 1988.

\title{
SUBSTITUTION OF ASPARAGINE RESIDUE AT THE C TERMINUS OF ESCHERICHIA COLI HEAT-STABLE ENTEROTOXIN
}

\author{
Jun YUKITAKE, Keinosuke OKAMOTO, Kyoko OKAMOTO \\ and Akio MIYAMA
}

Department of Microbiology, School of Medicine, Fujita-Gakuen Health University, Kutsukake, Toyoake, Aichi 470-11

Several enteropathogenic bacteria such as Escherichia coli, Yersinia enterocolitica and Vibrio cholerae non-O1 produce heat-stable enterotoxin (ST). The amino acid sequences at the $\mathrm{C}$ termini of these STs showed high similarity. Especially, the -Cys-Cys-Asn-Pro-Ala-Cys- sequence is conserved in all STs. Therefore, the conserved sequence is considered to be important for expression of ST activity. However, the relationship between the composed amino acids in this region and ST activity has not been clarified. We substituted each of Asp, Tyr, His, Gln, Lys and Arg, for the Asn residue at position 11 of STp (Asn-11) by oligonucleotide-directed site-specific mutagenesis and examined the biological activity of the culture filtrate of resultant mutants. The filtrates of all mutants reacted well with both monoclonal and polyclonal antibodies. This demonstrates that the amino acid substitution at position 11 does not cause a significant change in the conformation of ST. The enterotoxic activity of all culture filtrates decreased to less than $12 \%$ of that of wild type. Especially, the enterotoxic activity could not be detected in the culture filtrates of mutants producing ST (Arg-11) and ST (Lys-11). To confirm the enterotoxic activity of ST (Arg-11), we purified the mutant ST from culture filtrate by successive column chromatography on DEAESephacel, DEAE-Sephadex A-25, mono-Q FPLC (Pharmacia), Superlose 12 FPLC and Pep reversed phase FPLC. The purified ST (Arg-11) reacted with anti-ST antibody but did not show any enterotoxic activity. These results indicate that Asn-11 of STp plays an important role in enterotoxic activity.

\section{REFERENCES}

1. Okamoto, K., Okamoto, K., Yukitake, J., Kawamoto, Y. and Miyama, A. (1987): Infect. Immun., 55, 2121-2125.

2. Shimonishi, Y., Hidaka, Y., Koizumi, M., Hane, M., Aimoto, T., Takeda, T., Miwatani, T. and Takeda, Y. (1987): FEBS Let., 215, 165-170. 
Japan. J. Med. Sci. Biol., 41, 1988.

\title{
AN IMMUNOCHEMICAL STUDY ON O-ANTIGENIC (ENDOTOXIC) LIPOPOLYSACCHARIDES OF O1 VIBRIO CHOLERAE
}

\author{
Kazuhito HISATSUNE, Masahiro HAYASHI, Yuji HAISHIMA \\ and Seiichi KONDO
}

Department of Microbiology, School of Pharmaceutical Sciences, Josai University, Sakado, Saitama 350-02

Fructose is a rarely occurring neutral sugar as a component of lipopolysaccharides (LPS) of gram-negative bacteria. However, it is characteristically contained in $01 \mathrm{~V}$. cholerae LPS regardless of the biotype or serotype. Since heating $01 \mathrm{~V}$. cholerae LPS in dilute acetic acid at $100 \mathrm{C}$ results in release of fructose from LPS and concomitant loss of their antigenicity, it has been suspected that fructose is essentially associated with the antigenicity of LPS of this vibrio.

In the present study, the relationship between the release of fructose from 01 $V$. cholerae LPS and the decreased antigenicity in dilute acetic acid hydrolysis was kinetically examined with O1 V. cholerae NIH 41 (Ogawa) and 569B (Inaba) LPS. The decreased antigenic specificity of chemically treated LPS was assayed by passive hemolysis inhibition (PHI) analysis by use of antisera against the whole cell and factor sera A, B and C of O1 V. cholerae. The release of fructose from LPS completed within 30 min when both LPS were heated in $5 \%$ acetic acid at $100 \mathrm{C}$. However, the decrease in the antigenicity of LPS did not parallel with the release of fructose but delayed very much from the latter, showing a large gap between them.

On the other hand, periodate oxidation of both Ogawa and Inaba LPS resulted in elimination of all of both fructose and glucose and two-third of heptose constituents. However, the antigenicity of either LPS did not change after periodation as assayed by the PHI test with LPS as an inhibitor of the hemolytic system consisting of LPS-coated sheep blood cells, anti-NIH 41 or 569B antiserum and the guinea pig. These results are compatible with the interpretation that the fructose component of the LPS molecules of $01 \mathrm{~V}$. cholerae is not substantially associated with their antigenicity. 
Japan. J. Med. Sci. Biol., 41, 1988.

\section{ANALYSIS OF LIPID A EPITOPES BY VARIOUS MONOCLONAL ANTIBODIES}

Satoru ARATA, Jun-ichi MASHIMO, Mari UENO and Nobuhiko KASAI

Department of Microbial Chemistry, School of Pharmaceutical Sciences, Showa University, Hatanodai, Shinagawa-ku, Tokyo 142

Chemically synthesized lipid A analogues and bacterial lipid A preparations were analyzed for the in vitro antigenic reactivities by enzyme-linked immunosorbent assay (ELISA), the ELISA inhibition test, and immunodot assay with monoclonal and conventional antibodies. Seven monoclonal antibodies, including anti-E. coli F515 lipid A antibodies (Ec3G, Ec711G and Ec14G), anti-E. coli J5 lipid A antibodies (8A1 and 2A6), and anti-Pseudomonas dimunuta JCM 2788 lipid A antibodies (Pd6G and Pd4G), were used for these assays.

Ec3G and Ec711G, expressing similar reaction patterns, appeared to recognize the 1,4'-bis-phospholylated glucosamine disaccharide structure with suitable acyl groups, in which the acylation pattern of $E$. coli-type lipid A was not essential. Whereas, Ec14G had a specificity different from those of Ec3G and Ec711G. 8A1 was considered to be a widely cross-reactive antibody similar to that of the monoclonal antibody Sm161M, previously described (1-4). 2A6 was also a cross-reactive antibody, although the specificity was different from that of 8A1. Pd6G and Pd4G with specificities somewhat different each other appeared to recognize a specific lipid A structure of $P$. diminuta or $P$. vesicularis $(5,6)$.

Thus, in the present studies with monoclonal anti-lipid A antibodies of different origins, we demonstrated that lipid A produces various antibodies with similar or different specificities, and that serological specificities are derived from the backbone and/or acyl groups of the lipid A molecule, as described previously (14).

\section{REFERENCES}

1. Kasai, N., Arata, S., Mashimo, J., Okuda, K., Aihara, Y., Kotani, S., Takada, H., Shiba, T. and Kusumoto, S. (1985): Biochem. Biophys. Res. Commun., $128,607-612$.

2. Kasai, N., Arata, S., Mashimo, J., Okuda, K., Aihara, Y., Kotani, S., Takada, H., Shiba, T., Kusumoto, S., Imoto, M., Yoshimura, H. and Shimamoto, T. (1986): Infect. Immun., 51, 43-48.

3. Arata, S., Mashimo, J., Kasai, N., Okuda, K., Aihara, Y., Hasegawa, A. and Kiso, M. (1987): FEMS Microbiol. Lett., 44, 231-234. 
Japan. J. Med. Sci. Biol., 41, 1988.

4. Arata, S., Mashimo, J., Kasai, N., Okuda, K., Aihara, Y., Kotani, S., Takada, H., Shiba, T., Kusumoto, S., Shimamoto, T. and Kusunose, N. (1988): FEMS Microbiol. Lett., 49, 479-482.

5. Kasai, N., Arata, S., Mashimo, J., Akiyama, Y., Tanaka, C., Egawa, K. and Tanaka, S. (1987): Biochem. Biophys. Res. Commun., 142, 972-978.

6. Arata, S., Nakaya, K., Furuhashi, H., Nakamura, Y., Hirayama, T., Mashimo, J. and Kasai, N. (1988): Japan. J. Cancer Res. (Gann), 79, 626-631.

\section{LIPOPOLYSACCHARIDES FROM PROTEUS STRAINS USED IN WEIL-FELIX REACTION}

Ken-ichi AMANO, Sakae MIZUSHIRI, Kazue FUKUSHI and Mitsuru WATANABE1

Department of Bacteriology, Hirosaki University School of Medicine, Hirosaki, Aomori 036, and 1The Kitasato Institute, Minato-ku, Tokyo 108

Proteus strains OX2, OX19, and OXK are used as antigens of Weil-Felix (WF) reaction in the diagnosis of rickettsial diseases (1). However, little has been reported on the antigenic structures of the Proteus strains. Recently, we reported the structures of lipopolysaccharides (LPSs) of Rickettsia typhi, Rickettsia prowazekii, and Rickettsia tsutsugamushi (2-4). Then, we were interested in characterizing LPSs of Proteus strains used as the antigens of WF reaction.

The LPSs were extracted with phenol-water and purified by ultracentrifugation. Chemical analyses showed that OX2-LPS consists of quinovosamine (QuiN) and OX19-LPS and OXK-LPS of galactosamine (GalN) in addition to Glc, Gal, heptose (Hep), KDO, GlcN, uronic acid, phosphate, and fatty acids. SDS-PAGE revealed that each LPS was a mixture of smooth and semi-rough type LPSs. After hydrolysis with $2 \%$ acetic acid, LPS was separated into Opolysaccharide (OPS), oligosaccharide, and lipid A by centrifugation and Sephadex G-50 chromatography. OX2-OPS was composed of Glc, GlcN, and QuiN, and OXKOPS of Glc and GalN. We could not, however, analyze the composition of OX19OPS because it contained less OPS. The core regions, contained KDO, Hep, 
Japan. J. Med. Sci. Biol., 41, 1988.

phosphate, Glc, Gal, GlcN, and GalN and it seems that the structures of the core regions of three LPSs were slightly different one another. These lipid As were similar to that of Salmonella-type LPS.

ELISA using polyclonal rabbit antisera against Proteus whole cells and LPSs showed that the LPSs were strain-specific antigens, and the whole cells contained also common antigens. A decreased activity of antisera against OX2-LPS or OXKLPS was seen by absorption with homogeneous OPS. Finally, we examined the reactivity between the antisera against Proteus whole cells or LPSs and the whole cells of $R$. tsutsugamushi or $R$. typhi, but the results were all negative.

\section{REFERENCES}

1. Larsson, P. (1984): Meth. Microbiol., 14, 187-214.

2. Amano, K., Tamura, A., Ohashi, N., Urakami, H., Kaya, S. and Fukushi, K. (1987): Infect. Immun., 55, 2290-2292.

3. Amano, K., Mizushiri, S., Fukushi, K. and Williams, J. C. (1987): Japan. J. Med. Sci. Biol., 40, 197-198.

4. Amano, K. (1988): Seikagaku, 60, 255-265.

\section{EFFECT OF STRUCTURE AND BINDING POSITIONS OF ACYL SUBSTITUENTS IN SUBUNIT ANALOGUES OF LIPID A ON THEIR BIOLOGICAL ACTIVITIES}

Motohiro MATSUURA, Hiroaki TAKIMOTO, Mitsunobu NAKATSUKA, J. Yuzuru HOMMA, Satoru IKEDA1, Yoshio KUMAZAWA1, Chiaki NISHIMURA1, Akihiro YAMAMOTO2, Makoto KISO3 and Akira HASEGAWA3

The Kitasato Institute and 1 School of Pharmaceutical Sciences, Kitasato University, Minato-ku, Tokyo 108, 2Tokyo Institute for Immunopharm., Inc., Toshima-ku, Tokyo 171 and 3Department of Agricultural Chemistry, Gifu University, Gifu 501 11

Lipid A, the active principle of endotoxin, is composed of glucosamine disaccharide substituted with phosphoryl and acyl groups. In the course of studies 
Japan. J. Med. Sci. Biol., 41, 1988.

using chemically synthesized lipid A analogues, it was found that even the analogues constituted with monosaccharide structure can exhibit some of the activities of endotoxin $(1,2)$. We have been investigating the relationship between the structure and the biological activities of such analogues, 4-O-monophosphonoglucosamines with varied acyl substituents at 2- $\mathrm{N}$ - and 3-O-positions. In the present work, such an acyloxyacyl group as (R)-3-dodecanoyloxytetradecanoyl $\left(\mathrm{C}_{14}\right.$-O- $\left.\left(\mathrm{C}_{12}\right)\right)$, (R)-3-tetradecanoyloxytetradecanoyl $\left(\mathrm{C}_{14}\right.$-O$\left(\mathrm{C}_{14}\right)$ ) or $(\mathrm{R})$-3-hexadecanoyloxytetradecanoyl $\left(\mathrm{C}_{14}-\mathrm{O}-\left(\mathrm{C}_{16}\right)\right)$ group and such another acyl group as tetradecanoyl $\left(\mathrm{C}_{14}\right)$ or $(\mathrm{R})-3$-hydroxytetradecanoyl $\left(\mathrm{C}_{14}-\mathrm{OH}\right)$ group were introduced as the 2-N- and 3-O-acyl substituents and the effects of these acyl groups on the biological activities were examined.

In the activities of macrophage activation and mediator induction, no significant difference among the analogues possessing $\mathrm{C}_{14}-\mathrm{O}-\left(\mathrm{C}_{12}\right)$ and $\mathrm{C}_{14}-\mathrm{O}$ $\left(\mathrm{C}_{14}\right)$ as one of the acyl substituents was observed independent of the binding position, 2- $\mathrm{N}$ - or 3-O-, and of the other acyl substituent, $\mathrm{C}_{14}$ or $\mathrm{C}_{14}-\mathrm{OH}$. Activities of the analogues possessing $\mathrm{C}_{14}-\mathrm{O}-\left(\mathrm{C}_{16}\right)$ were low or scarce in all the activities examined. In mitogenic activity and antiviral activity against vaccinia virus infection, analogues possessing an acyloxyacyl group with a shorter carbon chain and $\mathrm{C}_{14}-\mathrm{OH}$ rather than $\mathrm{C}_{14}$ tended to express stronger activities. In the case of protective activity against $P$ seudomonas aeruginosa infection, analogues possessing $\mathrm{C}_{14}-\mathrm{O}-\left(\mathrm{C}_{12}\right)$ or $\mathrm{C}_{14}-\mathrm{O}-\left(\mathrm{C}_{14}\right)$ at 3-O-position rather than at $2-\mathrm{N}$ - position were effective. As for antitumor activity against Meth $\mathrm{A}$ fibrosarcoma, introduction of $\mathrm{C}_{14}-\mathrm{OH}$ as one of the acyl substituents rather than $\mathrm{C}_{14}$ was effective.

Based on these results, analogues possessing a hydroxyacyl and acyloxyacyl groups at 2-N- and 3-O-positions, respectively, are under further investigation more in detail by changing the carbon chain length of these acyl groups.

\section{REFERENCES}

1. Matsuura, M., Kojima, Y., Homma, J. Y., Yamamoto, A., Kiso, M. and Hasegawa, A. (1984): FEBS Lett., 167, 226-230.

2. Kumazawa, Y., Matsuura, M., Homma, J. Y., Nakatsuru, Y., Kiso, M. and Hasegawa, A. (1985): Eur. J. Immunol., 15, 199-201. 
Japan. J. Med. Sci. Biol., 41, 1988.

\title{
DETECTION OF HIGH- AND LOW-AFFINITY BINDING SITES OF CHOLESTEROL ON SHEEP AND HUMAN ERYTHROCYTE MEMBRANES WITH MODIFIED @-TOXIN OF CLOSTRIDIUM PERFRINGENS AS A PROBE
}

\author{
Yoshiko OHNO-IWASHITA, Machiko IWAMOTO, Ken-ichiro MITSUI1, \\ and Susumu ANDO
}

Department of Biochemistry, Tokyo Metropolitan Institute of Gerontology, 35-2, Sakae-cho, Itabashi-ku, Tokyo 173 and 1Toyama Medical and Pharmaceutical University, Toyama 930-01

$\Theta$-Toxin (perfringolysin 0 ) has been reported to damage a wide variety of cells such as erythrocytes $(1,2)$ and rat hepatocytes (3) after adsorption on membrane cholesterol. We obtained by limited proteolysis with subtilisin Carlsberg a nicked $\Theta$-toxin $(\mathrm{C} \Theta)(1)$, which barely caused hemolysis below $20 \mathrm{C}$ due to its higher Arrhenius activation energy for hemolysis than that of native $\Theta$ toxin. Not only the apparent affinity of $\mathrm{C} \Theta$ for membrane cholesterol but also the degree of inhibition by various cholesterol analogues are comparable to those of $\Theta$ toxin both at 20 and $37 \mathrm{C}$, suggesting that the structure of the cholesterol-binding site in $C \Theta$ is maintained nearly intact even at low temperatures. On the other hand, neither electron microscopic evidence for the formation of arc- and ringshaped structures on the membrane nor toxin-stimulated influx of extracellular $\mathrm{Ca}^{2}+$ was detected on $\mathrm{C} \Theta$-treated cells below $20 \mathrm{C}$.

Taking advantage of the high affinity for cholesterol and the lack of any obvious disturbance of membrane integrity at low temperatures, we investigated the toxin-binding sites on sheep erythrocytes with $\mathrm{C} \Theta$ as a probe. Scatchard analysis showed the possible existence of two types of binding sites with high and low affinities to the toxin. Both binding sites disappeared by simultaneous treatment of the cells with sublytic doses of digitonin. Furthermore, $\mathrm{C} \Theta$ bound only to cholesterol among the chloroform/methanol-extractable lipidic components of sheep and human erythrocytes (4). These results strongly suggest that cholesterol is an essential component of both the high- and low-affinity sites and also imply that the modes of existence of cholesterol in the red cell membrane are heterogeneous. 
Japan. J. Med. Sci. Biol., 41, 1988.

\section{REFERENCES}

1. Ohno-Iwashita, Y., Iwamoto, M., Mitsui, K., Kawasaki, H. and Ando, S. (1986): Biochemistry, 25, 6048-6053.

2. Iwamoto, M., Ohno-Iwashita, Y. and Ando, S. (1987): Eur. J. Biochem., 167, 425-430.

3. Zs.-Nagy, I., Ohno-Iwashita, Y., Ohta, M., Zs.-Nagy, V., Kitani, K., Ando, S. and Imahori, K. (1988): Biochim. Biophys. Acta, 939, 551-560.

4. Ohno-Iwashita, Y., Iwamoto, M., Mitsui, K., Ando, S. and Nagai, Y. (1988): Eur. J. Biochem., 176, 95-101.

\section{ANTIGENIC STRUCTURE AND BINDING KINETICS OF CLOSTRIDIUM BOTULINUM TYPE B NEUROTOXIN}

Jun OGASAWARA, Shunji KOZAKI, Yoichi KAMATA and Genji SAKAGUCHI

College of Agriculture, University of Osaka Prefecture, Sakai-shi, Osaka 591

A hitherto unknown fragment $\left(\mathrm{M}_{\mathrm{r}}=115,000\right)$ distinct from either the heavy $\left(\mathrm{M}_{\mathrm{r}}=105,000\right)$ or light $\left(\mathrm{M}_{\mathrm{r}}=54,000\right)$ chain was obtained upon treating Clostridium botulinum type $B$ neurotoxin $\left(M_{r}=155,000\right)$ with chymotrypsin. This fragment, whether reduced or not, migrated in SDS-PAGE in a single band. When treated with lysyl endopeptidase and then dithiothreitol, the fragment was cleaved into two chains, one of which corresponded to the light chain. Enzyme-linked immunosorbent assay and immunoblotting analyses with monoclonal antibodies showed the fragment to consist of the light chain (L) and an amino-terminal half portion of the heavy chain (H-1) linked together with a disulfide bond. The fragment was named L.H-1. The carboxyl-terminal half portion of the heavy chain $(\mathrm{H}-2)$ seemed to have been digested by chymotrypsin.

The neurotoxin and its fragments were tested directly by the TLCimmunostaining method for the binding to gangliosides. The neurotoxin and the heavy chain bound to gangliosides $\mathrm{G}_{\mathrm{T} 1 \mathrm{~b}}$ and $\mathrm{G}_{\mathrm{D} 1 \mathrm{a}}$; whereas the $\mathrm{L} \cdot \mathrm{H}-1$ fragment or the light chain did not. The L.H-1 fragment did not inhibit the binding of $125 \mathrm{I}$ - 
Japan. J. Med. Sci. Biol., 41, 1988.

labeled neurotoxin to mouse brain synaptosomes. These observations suggest that the $\mathrm{H}-2$ portion of type $\mathrm{B}$ neurotoxin is the site that binds to the acceptor.

To characterize the acceptor on type $B$ neurotoxin, mouse brain synaptosomes were treated with some enzymes and examined for their binding kinetics. The amount of 125I-labeled neurotoxin bound decreased upon treating synaptosomes with lysyl endopeptidase, neuraminidase or phospholipase $\mathrm{C}$. The reduced amount of neurotoxin bound was restored upon incubation of the neuraminidase-treated synaptosomes with gangliosides $\mathrm{G}_{\mathrm{T} 1 \mathrm{~b}}$ or $\mathrm{G}_{\mathrm{D} 1 \mathrm{a}}$, that are capable of binding the neurotoxin. Gangliosides were incorporated into untreated and lysyl endopeptidase-treated synaptosomes, but the amount of the neurotoxin bound did not increase. Incubation of the phospholipase C-treated synaptosomes with gangliosides did not restore the reduced amount of the binding of the neurotoxin. These results suggest that type B neurotoxin binds to gangliosides in cooperation with some protease-sensitive substance on the neural membranes, and that the binding mechanism of the neurotoxin may involve a minor contribution by phospholipids. 
Japan. J. Med. Sci. Biol., 41, 1988.

INHIBITORY EFFECTS OF LIPOPOLYSACCHARIDES ON MURINE B CELL LINES, CYG34 AND CYG101, AND IDENTIFICATION OF Re LPSBINDING PROTEIN ON CELL MEMBRANE OF MURINE LYMPHOID CELL LINES

Teruo KIRIKAE, Fumiko HONDA-KIRIKAE, Katsuya INADA, Masao YOSHIDA, Kazuhito HISATSUNE1, Yuji HAIJIMA1 and Shinichi NISHIKAWA2

Department of Bacteriology, School of Medicine, Iwate Medical University, Morioka, Iwate 020,1Department of Microbiology, School of Pharmaceutical Sciences, Josai University, Sakado, Saitama 350-02 and 2Department of Pathology, Institute for Medical Immunology, Medical School, Kumamoto University, Kumamoto 860

Previously, we developed a method for detecting bacterial lipopolysaccharide (LPS)-binding proteins on nitrocellulose (NC) membrane (1). This method demonstrated that Re-mutant LPS was bound to a single protein band of $96 \mathrm{k}$ daltons of murine erythrocyte membrane. In the present study, to clarify the properties of the functional LPS receptor, LPS-responsiveness and LPS-binding proteins on a number of murine cell lines were examined.

As the results, it was found that LPS profoundly inhibited the growth of murine B-cell lines, designated CYG34 and CYG101, established from long-term bone marrow cultures. When CYG101 cells were cultured together with Re LPS at $2-100 \mu \mathrm{g} / \mathrm{ml}$, the cell proliferation was dose-dependently suppressed. Re LPS also slightly inhibited the growth of Pre-B cell lines, 70Z/3 and CYG8, and a myeloma cell line, X63Ag8. However, the growth of T-cell line, BW5147, was not affected by Re LPS. The growth of CYG101 was inhibited by S-form LPS, Re-mutant LPS and lipid A, but not by degraded polysaccharide of S LPS. These results suggest that the growth inhibition of cell lines by LPS is selective or specific to the cell line and that the lipid A portion of LPS is involved in this growth inhibition.

In the next examination, Re LPS-binding proteins on cell membranes of these cell lines were identified. Re LPS was bound to a single band of membrane protein of pre-B-cell lines, 70Z/3. Its molecular weight was $40 \mathrm{k}$ daltons in the presence of and $45 \mathrm{k}$ daltons in the absence of a reductant ( $\mathrm{p}-40 / 45)$. The $\mathrm{p}-40 / 45$ protein was detected also in other murine lymphoid cell lines. However, the amounts were different among cell lines. The amounts of Pre-B cell lines and B cell lines were 
Japan. J. Med. Sci. Biol., 41, 1988.

larger than those of a $\mathrm{T}$ cell line and a myeloma cell line. This $\mathrm{p}-40 / 45$ protein may be an LPS receptor on murine lymphoid cells. However, we were not able to show the correlation between the amount of this protein and the growth inhibition of cell lines by LPS. Further studies are necessary to identify the functional LPSreceptor.

\section{REFERENCE}

1. Kirikae, T., Inada, K., Hirata, M., Yoshida, M., Kondo, S. and Hisatsune, K. (1988): Microbiol. Immunol., 32, 33-44.

IDENTIFICATION OF RECEPTORS OF ESCHERICHIA COLI HEATSTABLE ENETEROTOXIN ON CELL MEMBRANE OF RAT INTESTINE BY PHOTOAFFINITY LABELING

Toshiya HIRAYAMA, Yuichi OKU, Futami MATSUDA, Naomi NAKABAYASHI, Keiko MATSUMOTO, Yoshifumi TAKEDA, Naohito IWATA1, Saburo AIMOTO1, and Yasutsugu SHIMONISHI1

The Institute of Medical Science, The University of Tokyo, Shirokanedai, Minatoku, Tokyo 108, and 1Institute for Protein Research, Osaka University, Osaka 565

The receptors for heat-stable enterotoxin produced by enterotoxigenic Escherichia coli (STh) on rat intestinal cell membrane was identified by using radioiodinated synthetic active fragment $\mathrm{STh}$ [5-19] which is covalently coupled through the $\mathrm{N}$-terminus to the photoreactive regent of $\mathrm{N}$-5-azido-2nitrobenzoyloxysuccinimide. Incubation of rat intestinal cell membrane with radioiodinated N-5-azido-2-nitrobenzoyl-STh[5-19] followed by photolysis resulted in specific radiolabeling of four protein bands, R-I, R-II, R-III, and R-IV, on SDS-gel electrophoresis. R-IV had a molecular size of $59 \mathrm{k}$-daltons and an isoelectric point of 6.0. R-III was a diffuse band at 77-81k-daltons with an isoelectric point of about 
Japan. J. Med. Sci. Biol., 41, 1988.

7.0. These two bands, R-III and R-IV, were previously shown as receptor proteins for STh by both photoaffinity labeling (1) and affinity cross-linking (2). The molecular weights of R-I and R-II were estimated to be $160 \mathrm{k}$ and $150 \mathrm{k}$, respectively.

The photoaffinity labeling of these four proteins was completely inhibited not only by active fragment of STh but also by both active fragments of heat-stable enterotoxins of Yersinia enterocolitica (Y-ST) and Vibrio cholerae non-O1 (NAGST). However, atrial natriuretic paptide (rat ANP [3-28]), which activates particulate guanylate cyclase in a similar manner as STh, was ineffective in competiting for the photoaffinity labeling of the four bands. These results indicate that the STh-receptors, R-I, R-II, R-III, and R-IV, are common to Y-ST and NAGST.

\section{REFERENCES}

1. Kuno, T., Kamisaki, Y., Waldman, S. A., Gariepy, J., Schoolnik, G., and Murad, F. (1986): J. Biol. Chem., 261, 1470-1476.

2. Gariepy, J. and Schoolnik, G. K. (1986): Proc. Natl. Acad. Sci., USA, 83, 483487.

FEATURES OF IONIC CURRENTS OF SMOOTH MUSCLE CELL MEMBRANES AND ACTIONS OF SOME TOXINS ON THEIR IONIC CHANNELS

Hirosi KURIYAMA, Kenji KITAMURA and Kenji SAKAI

Department of Pharmacology, Faculty of Medicine, Kyushu University, Fukuoka 812

After successful applications of the whole cell clamp and patch clamp methods, features of smooth muscle membrane became clear. The main inward 
Japan. J. Med. Sci. Biol., 41, 1988.

current is composed of a $\mathrm{Ca}$ inward and partly a $\mathrm{Na}$ inward current. The $\mathrm{Ca}$ inward current is composed of the voltage-dependent $\mathrm{Ca}$ and receptor-operated $\mathrm{Ca}$ channels. The former is classified into $\mathrm{L}, \mathrm{T}$ and $\mathrm{N}$ subtypes ( $\mathrm{N}$ is only distributed on nerve fibers) from various biophysical parameters. $\omega$-Conotoxin is a selective inhibitory toxin for the $\mathrm{L}$ and $\mathrm{N}$ subtypes in nerve cells but this toxin does not show any effect on the $\mathrm{L}$ subtype of smooth or cardiac muscles. The Na current is not thought to be generated in smooth muscles, as measured with the microelectrode, however, by application of the whole cell clamp method, the presence of the $\mathrm{Na}$ current is elucidated. This $\mathrm{Na}$ channel evoked in smooth muscle membranes is highly sensitive to tetrodotoxin to the same extent as that observed on nerve fibers, but it occurs to a greater extent than that observed on is highly sensitive to tetrodotoxin to the same extent as that observed on nerve fibers, but it occurs to a greater extent than that observed on cardiac muscles. The outward current evoked in smooth muscle membranes is mainly composed of Ca-dependent and independent $\mathrm{K}$ currents. The former is composed of intra- and extra-cel ' alar Cadependent $\mathrm{K}$ channels. Apamin only inhibited a subtype of Ca-dependent $\mathrm{K}$ channels activated by the $\mathrm{K}$ channel agonist.

The basic features of ionic channels observed from smooth muscles seem to be the same as those observed from other excitable cells, but specific features differ from those of cardiac and skeletal muscles. Applications of newly elucidated toxins may promote further advances of investigations of the ionic channel in smooth muscles. 
Japan. J. Med. Sci. Biol., 41, 1988.

STRUCTURE AND FUNCTION RELATIONSHIP OF TETANUS TOXIN: BLOCKADE OF SYNAPTIC TRANSMISSION BY FRAGMENT [A-B], THE N-TERMINAL FRAGMENT OF TETANUS TOXIN

\author{
Kunihiro OZUTSUMI, Kohsi TAKANO1, Andreas GREMMELT1, \\ Nakaba SUGIMOTO and Morihiro MATSUDA
}

Research Institute for Microbial Diseases, Osaka University, 3-1 Yamadaoka, Suita, Osaka 565, and 1 Abteilung Pathoneurophysiologie, Universitaet Goettingen, Humboldtallee 23, D-3400 Goettingen, F.R.G.

Tetanus toxin is a simple protein with a molecular weight of about 150,000. The toxin is known to block synaptic transmission in the central nervous system and neuromuscular transmission in the peripheral neuromuscular junction.

The toxin molecule has been proposed to have three different domains with similar molecular weights of about 50,000 . Of these three domains, the $\mathrm{N}$-terminal fragment, Fragment [A-B], prepared by digesting the toxin mildly with papain has been reported to elicit an atypical toxicity $(1,2)$. However, recently, Simpson et al. (3) reported that the toxicity ascribed to Fragment [A-B] is due to a trace amount of tetanus toxin having contaminated the fragment preparations and concluded that Fragment $[\mathrm{A}-\mathrm{B}]$ has no such toxicity.

In this study, we prepared Fragment [A-B] free from contamination of whole toxin and examined its toxicity.

Fragment [A-B] was prepared by mild papain treatment of the tetanus toxin and purified by combination of HPLC gel filtration, adsorption on an HPLC hydroxyapatite column and passing through an immunoadsorption column incorporated anti-Fragment [C] (Fragment [C]: a complementary fragment of Fragment [A-B]) antibody as a ligand.

When injected with highly purified Fragment $[A-B]$, the mice never showed spastic paralysis, but showed peculiar symptoms, hypoactiveness and weakness, which developed with a latency of about $48 \mathrm{hr}$. On the other hand, when injected with whole tetanus toxin, the mice never showed such symptoms, but showed spastic paralysis typical to tetanus intoxication with a latency of about $15 \mathrm{hr}$ or longer. Thus, the results clearly show that Fragment [A-B] has a peculiar toxicity different from that of tetanus whole toxin.

By electrophysiological analyses, unlike the whole tetanus toxin which blocked inhibitory synapses prior to excitatory synapses, the purified Fragment 
Japan. J. Med. Sci. Biol., 41, 1988.

[A-B] was found to block both excitatory and inhibitory synapses almost simultaneously.

These results strongly suggest that Fragment [A-B] carries the active domain(s) of tetanus toxin.

\section{REFERENCES}

1. Helting, T. B., Ronneberger, H. J., Vollerthun, R. and Neubauer, V. (1978): J. Biol. Chem., 253, 125-129.

2. Matsuda, M., Sugimoto, N. and Ozutsumi, K. (1982): Proc. 6th Int. Conf. Tetanus. Foundation Merieux, Lyon, p.21-32.

3. Simpson, L. L and Hoch, D. H. (1985): J. Pharmacol. Exptl. Therap., 232, 223-227.

\section{AN ATTEMPT TO INTRODUCE ENCEPHALOPATHY WITH PERTUSSIS TOXIN IN MICE}

Hiroko SATO and Yuji SATO1

Departments of Applied Immunology, and 1Bacteriology, National Institute of Health, Kamiosaki, Shinagawa-ku, Tokyo 141

Pertussis continues to be a serious disease in infants and children. Some of patients with serious disease suffer from permanent brain damage. Although pertussis vaccine is effective in providing protection, world-wide publicity about adverse reactions has raised concern about its safety. Most of the literature concerning the possibility that pertussis vaccine might cause brain damage, socalled encephalopathy, in children consists of case reports. The causative agents or mechanism of encephalopathy, however, has not been identified, because there is yet no satisfactory animal model for encephalopathy. Development of an animal model for so rare post-vaccination encephalopathy as its rate has been reported as 1 to 50,000-300,000 doses, might be impossible. As an initial step, we have tried to introduce a kind of encephalopathy in mice with pertussis toxin (PT), being the most important protective antigen in the vaccine. 
Japan. J. Med. Sci. Biol., 41, 1988.

It is well known that the mice injected intracerebrally with virulent pertussis organisms show encephalopathic and hyper-excitable behavior. We found that PT alone also caused this hyper-excitable behavior together with ulcer around the eyes in mice by ic administration. In this communication, we call these symptoms "encephalopathy" for convenience. Twelve strains of mice in five different haplotypes were tested for their susceptibilities to P'T-induced encephalopathy. There were different susceptibilities among strains but not among haplotyeps. Since ddy strain of mice used mostly in our laboratory showed a high susceptibility to the encephalopathy induction, it was employed in this study although its haplotype is not yet known. The mice injected intracerebrally with $500 \mathrm{ng}$ of PT showed encephalopathy in 3 or more days and all died within 2 weeks. LD 50 of PT injected intracerebrally was $200 \mathrm{ng}$. A smaller amount of PT took a longer period before onset of encephalopathy or death. The mice treated with $63 \mathrm{ng}$ of PT showed encephalopathy from the 10th day and some of them died from the 2nd week. Mostly, the hyper-exciting behavior and ulcer appeared in parallel and the both symptoms became serious day by day. Encephalopathy was prevented with monoclonal or polyclonal anti-PT antibody administered by the ic or ip route. No encephalopathy was caused with pertussis toxoid or PT subunits. Other ADPribosylating toxins such as cholera toxin (CT), diphtheria toxin (DT) and Pseudomonas aeruginosa exotoxin A (ETA), were also tested for their encephalopathy-inducing activity by ic injection to mice. $\mathrm{LD}_{50}$ of DT and ETA were $6 \mathrm{ng}$ and $50 \mathrm{ng}$, respectively. CT presented neither lethality nor encephalopathy. DT showed also hyper-irritability and stereotypy in the mice with dose-dependency although DT did not cause such ulcer around the eye as did PT. PT or DT did not induce encephalopathy in mice by iv or sc injection. Histopathological examinations of the brain of the mice injected intracerebrally with PT showed characteristic ventriculo-meningitis but no encephalitis. Relation between the histological changes and hyper-excitability or ulcer in mice is still unclear. In postmortem examination of a child injected with pertussis vaccine, no such characteristic histological changes have been reported. PT-induced encephalopathy in mice might be distinct from the brain damages in children. More detailed histopathological changes of the brain of mice injected by different routes with various amounts of PT are now under investigation.

(This research was supported by a Grant-in-Aid for General Scientific Research from The Ministry of Education, Science and Culture). 
Japan. J. Med. Sci. Biol., 41, 1988.

\title{
EFFECTS OF STAPHYLOCOCCAL EXOTOXIN, TOXIC SHOCK SYNDROME TOXIN-1 ON IN VITRO ANTIBODY RESPONSES OF MICE
}

\author{
Xiao-jie YAN, Shinji SAITO, Takehiko UCHIYAMA, \\ Hiroshi FUJIKAWA1 ${ }^{1}$ and Hideo IGARASHI 1
}

Department of Microbiology, Tokyo Women's Medical College, Kawada-cho 8-1, Shinjuku-ku, Tokyo 162, and 1The Tokyo Metropolitan Research Laboratory of Public Health, 3-24-1 Hyakunin-cho, Shinjuku-ku, Tokyo 160

Toxic shock syndrome toxin-1 (TSST-1), an exotoxin produced by Staphylococcus aureus isolated from patients with toxic shock syndrome (TSS), is thought to be a causative agent of TSS. We have shown that TSST- 1 has various effects on murine and human lymphoid cells (1-5). In the present study, we investigated the modulatory activity of TSST- 1 on antibody response of $\mathrm{C} 57 \mathrm{BL} / 6$ mice to sheep red blood cells (SRBC), using an in vitro culture system. Anti-SRBC antibody response was markedly reduced in whole spleen cells from mice injected with $10 \mu \mathrm{g}$ of TSST-1 2 days before cultivation. In contrast, antibody response of T-depleted spleen cells from mice similarly treated was higher than that of the control group when stimulated with SRBC in the presence of normal T cells. The mechanisms of reduction and enhancement of antibody response observed were analyzed. Spleen cells from TSST-1-preinjected mice suppressed the development of antibody response of normal spleen cells. Removal of $\mathrm{T}$ cells abrogated the suppressive activity showing that suppressor $\mathrm{T}$ cells were generated in spleen cells of TSST-1-preinjected mice. On the other hand, purified B cells from TSST-1preinjected mice developed much higher antibody response than did normal B cells when stimulated with SRBC in the presence of $T$ cells and peritoneal exudate cells from normal mice. The LPS-induced proliferative response of B cells was also higher in TSST-1 preinjected mice than in control mice. The enhancement of LPSinduced B cell proliferation was not observed in TSST-1-preinjected nude mice, showing that TSST-1-induced B cell activation observed is mediated by the presence of $\mathrm{T}$ cells. Taken together, these results indicate that TSST-1 induced the multiple effects on antibody response, generation of suppressor $\mathrm{T}$ cells and $\mathrm{T}$ cellmediated $\mathrm{B}$ cell activation. 
Japan. J. Med. Sci. Biol., 41, 1988.

\section{REFERENCES}

1. Uchiyama, T., Kamagata, Y., Wakai, M., Yoshioka, M., Fujikawa, H. and Igarashi, H. (1986): Microbiol. Immunol., 30, 465-483.

2. Uchiyama, T., Kamagata, Y., Yan, X. J., Kohno, M., Yoshioka, M., Fujikawa, H., Igarashi, H., Okubo, M., Awano, F., Saito-Taki, T. and Nakano, M. (1987): Clin. Exptl. Immunol., 68, 638-647.

3. Kamagata, Y., Oka, M., Uchiyama, T., Yoshioka, M., Fujikawa, H. and Igarashi, H. (1987): J. Japan. Assoc. Infect. Dis., 61, 907-913 (text in Japanese).

4. Fujikawa, H., Igarashi, H., Usami, H., Kawabata, S. and Morita, T. (1984): Infect. Immun., 44, 175-181.

5. Yan, X. J., Uchiyama, T., Kawachi, A., Yoshioka, M., Fujikawa, H. and Igarashi, H. (1988): J. Japan. Assoc. Infect. Dis., 62, 483-489 (text in Japanese).

\section{MECHANISMS OF MACROPHAGE ACTIVATION BY BACTERIAL LIPOPOLYSACCHARIDES: DEFECTIVE SITE ON LPS- UNRESPONSIVE C3H/HeJ PERITONEAL MACROPHAGES}

Yasuhiko TERADA, Hiroto SHINOMIYA and Masayasu NAKANO

Department of Microbiology, Jichi Medical School, 3311-1, Yakushiji, Minamikawauchi-machi, Kawauchi-gun, Tochigi 329-04

Bacterial lipopolysaccharide (LPS)-unresponsive C3H/HeJ (HeJ) mice are a mutant strain derived by a point mutation on LPs locus in chromosome 4 from LPS-responsive $\mathrm{C} 3 \mathrm{H} / \mathrm{He}(\mathrm{He})$ mice. Cultured peritoneal exudate He-macrophages $(\mathrm{M} \phi)$ can produce interleukin-1 (IL-1) by stimulation with LPS or a calcium ionophore (A23187). However, HeJ-M $\Phi$ cannot produce any IL-1 by the stimulation (1). Northern blot analysis revealed that He-M $\Phi$ expressed IL-1 $\beta$ mRNA after the stimulation, while HeJ-M $\phi$ did not. To analyze the intracellular pathways of signal transmission for IL-1 production, effects of various inhibitors of the calcium-dependent pathway were examined. The addition of calmodulin (CaM) inhibitors (W-7) to the cultures of He-M $\Phi$ blocked the calcium ionophoreinduced IL-1 $\beta$ mRNA expression, while a protein kinase C (PKC) inhibitor (H-7) did not show any inhibitory effect on the mRNA expression. On the other hand, 
Japan. J. Med. Sci. Biol., 41, 1988.

there is a difference in the accumulation of CaM-binding protein in the $M \Phi$ but not in CaM function. These data suggest that the calcium-CaM system is involved in macrophage activation by LPS and the unresponsiveness of IL-1 production by HeJ-M $\Phi$ to A23187 and LPS is due to a functional defect in some part of the calcium-CaM-dependent pathway, but not in the PKC pathway.

\section{REFERENCE}

1. Shinomiya, H. and Nakano, M. (1987): J. Immunol., 139, 2730.

\section{EFFECT OF CLOSTRIDIUM PERFRINGENS \&-TOXIN ON THE ISOLATED RAT INTESTINE}

Masahiro NAGAHAMA, Toshihiro TAKAHASHI, Keiko KOBAYASHI and Jun SAKURAI

Department of Microbiology, Faculty of Pharmaceutical Sciences, Tokushima Bunri University, Yamashiro-cho, Tokushima 770

Clostridium perfringens epsilon toxin has been thought to be an important agent in enterotoxemia caused by type $\mathrm{D}$ strains. The toxin is lethal and dermonecrotic. We have reported the relationship between amino acid residues and the lethal activity of the toxin (1-6). On the other hand, some workers reported that the toxin increases the vascular permeability in the brains and the intestines. We have reported also that it elevates the blood pressure (7). However, little can be said concerning the role of the toxin in the pathogenesis of the disease. Therefore, to approach the mode of in vivo action of the toxin, the effects of the toxin on the isolated rat intestine were investigated.

Epsilon toxin was purified from culture supernatant fluid of C. perfringens type D NCTC 8346 as described previously (7). The procedure of preparing the rat intestine and the technique for measurement of the contractions were the same as described previously. 
Japan. J. Med. Sci. Biol., 41, 1988.

Epsilon toxin induced contraction of the isolated intestine in the dosedependent manner $(200 \mathrm{ng} / \mathrm{ml}-1 \mathrm{\mu g} / \mathrm{ml})$. The toxin-elicited contraction was not observed in the low $\mathrm{Na}+$-medium, but was restored by the addition of $\mathrm{Na}+$ into the medium. Furthermore, tetrodotoxin, which is thought to block the excitation and conduction of nerves, inhibited contraction caused by the toxin in the dosedependent manner. In addition, contraction caused by the toxin was blocked by atropine and mecamylamine. The data suggest that the toxin acts at least on the autonomic nervous system, and then induces contraction of the isolated intestine by such a transmitter as acetylcholine released from nerve endings.

\section{REFERENCES}

1. Sakurai, J. and Nagahama, M. (1985): Infect. Immun., 47, 260-263.

2. Sakurai, J. and Nagahama, M. (1985): Biochem. Biophys. Res. Commun., 128, 760-766.

3. Sakurai, J. and Nagahama, M. (1986): Microbial Pathogen., 1, 417-423.

4. Sakurai, J. and Nagahama, M. (1987): Toxicon, 25, 279-284.

5. Sakurai, J. and Nagahama, M. (1987): FEMS Microbiol. Lett., 41, 317-319.

6. Sakurai, J. and Nagahama, M. (1987): Microbial Pathogen., 3, 469-474.

7. Sakurai, J., Nagahama, M. and Fujii, Y. (1983): Infect. Immun., 42, 11831186.

\section{ACTION OF BORDETELLA HEAT-LABILE TOXIN ON VASCULAR SMOOTH MUSCLE CELLS AND ITS BINDING TO THE CELLS}

Masaaki NAGAI, Masahiko ENDOH and Yasukiyo NAKASE

Department of Microbiology, School of Pharmaceutical Sciences, Kitasato University, Minato-ku, Tokyo 108

Bordetella heat-labile toxin (HLT) induces a contraction of the vascular smooth muscles and their cultured cells from aortas of guinea pigs and pigs (1-3). In parallel with induction of the contraction, the membrane permeability of the cells was remarkably increased (3). In this study, we attempted to approach the 
Japan. J. Med. Sci. Biol., 41, 1988.

mechanisms by which HLT bound to vascular smooth muscle cells and increased the membrane permeability.

The permeability-increasing effect of HLT changed depending on the incubation temperature and the HLT dose. This ability was blocked in dosedependent manner ( 0.03 to $0.3 \mathrm{mM}$ ) by the addition of dextran of mol. wt. 8,000, but not of mol. wt. 5,000 , before the induction of this change. When 125I-HLT was added, its binding to the cells occurred immediately depending on the dose of HLT (30 to $300 \mathrm{MID} / \mathrm{ml}$ ), and then reached maximum within $60 \mathrm{~min}$. At $37 \mathrm{C}$, the maximum binding ratio was approximately $0.8 \%$ of total HLT added. At $4 \mathrm{C}$, it was less than $20 \%$ of that at $37 \mathrm{C}$. The labeled HLT bound to the cells was released easily by washing with a warmed fresh medium or by addition of a large quantity (100-fold) of unlabeled HLT. The specific binding ratio of 125I-HLT ( $30 \mathrm{MID} / \mathrm{ml}$ ) to the cells was measured in the presence of increasing concentrations of unlabeled HLT (15 to 3,000 MID/ml) in $60 \mathrm{~min}$ after exposure. Scatchard analysis indicated two classes of the binding site. The $\mathrm{K}_{\mathrm{a}}, \mathrm{K}_{\mathrm{d}}$ and $\mathrm{B}_{\max }$ values were 2.1 and $9.6 \times 10^{9}$ $\mathrm{M}-1,4.8$ and $1.0 \times 10^{-10} \mathrm{M}$, and 4.8 and $2.2 \mathrm{fmol} / \mathrm{dish}$, respectively. Since the number of the cells in a dish was $2.3 \times 105$, the maximum number of HLT molecules bound to a single cell was calculated at $5.7 \times 10^{3}$. In the cells contracting by HLT, no significant change in the composition of such main phospholipids as phosphatidyl choline, phosphatidyl ethanolamine and phosphatidyl serine was found.

These data indicate that HLT changes the membrane permeability depending on the incubation temperature by binding immediately and reversibly to the vascular smooth muscle cells, resulting in their contraction. These facts suggest that HLT seems to act like an enzyme.

\section{REFERENCES}

1. Endoh, M., Nagai, M. and Nakase, Y. (1986): Microbiol. Immunol., 30, 12391246.

2. Endoh, M., Nagai, M., Ueda, T., Yoshida, Y. and Nakase, Y. (1988): Microbiol. Immunol., 32, 423-428.

3. Endoh, M., Nagai, M. and Nakase, Y. (1988): Microbiol. Immunol., 32, 755767. 
Japan. J. Med. Sci. Biol., 41, 1988.

\title{
INHIBITION OF THE RELEASE OF VARIOUS NEUROTRANSMITTERS FROM FETAL RAT BRAIN CELLS IN DISSOCIATED CULTURE BY BO'TULINUM NEUROTOXINS
}

\author{
Naomi YASUNO, Ichiro MATSUOKA, Bunei SYUTO1, \\ Kohji MIRIISHI 1 and Kenzo KURIHARA
}

Faculty of Pharmaceutical Sciences and 1Faculty of Veterinary Medicine, Hokkaido University, Sapporo 060

Cells dissociated from midbrains of fetal rats (16 days of gestation) were cultured for periods up to 12 days for the purpose of studying the action of botulinum neurotoxins on the release of various transmitters from neuronal cells. Cultured brain cells underwent neuronal differentiation as indicated by extensive process formation and increasing capacities of uptake of $[3 \mathrm{H}]$ norepinephrine (NE) and depolarization (highpotassium)-evoked release of $[3 \mathrm{H}] \mathrm{NE}$ in 3 to 6 days in vitro. The depolarization-evoked release of $[3 \mathrm{H}] \mathrm{NE}$ was dependent on the external $\mathrm{Ca}^{2}+$ concentration higher than $0.2 \mathrm{mM}$. Incubation of cells with botulinum neurotoxin type A, C1 (strains Cst and C6813) or D (strains Dsa and D1873) at 37 $\mathrm{C}$ for 1-4 hr inhibited the depolarization-evoked release of all kinds of transmitters examined (NE, dopamine, 5-HT, GABA). The neurotoxins had no effect on the uptake of $[3 \mathrm{H}]$-labeled neurotransmitters. As shown in Table $\mathrm{I}$ the neurotoxins types A, C1 (C6813, Cst) and D (D1873) inhibited the release of all transmitters with potencies $\left(\mathrm{IC}_{50}=0.03-0.5 \mathrm{\mu g} / \mathrm{ml}\right)$ similar to that of inhibition by Cst toxin of ACh release from brain synaptosomes $\left(\mathrm{IC}_{505}=0.01 \mathrm{\mu g} / \mathrm{ml}\right)$, while the Dsa toxin was less potent $\left(\mathrm{IC}_{50} \geqq 10 \mu \mathrm{g} / \mathrm{ml}\right)$.

Table I. $\mathrm{IC}_{50}(\mu \mathrm{g} / \mathrm{ml})$ of botulinum neurotoxins on the inhibition of transmitter release from dissociated brain cells in culture

\begin{tabular}{lclccc}
\hline & A & Cst & C6813 & D1873 & Dsa \\
\hline NE & 0.5 & 0.05 & 0.1 & 0.5 & $\sim 10$ \\
Dopamine & - & 0.03 & 0.2 & 0.3 & $\geqq 10$ \\
5-HT & 0.05 & 0.4 & 0.1 & 0.4 & $\geqq 10$ \\
GABA & - & 0.3 & - & - & - \\
\hline
\end{tabular}


Japan. J. Med. Sci. Biol., 41, 1988.

When cultured brain cells were permeabilized with digitonin, release of $[3 \mathrm{H}]-$ labeled transmitters was evoked by $\mathrm{Ca}^{2}+$ (half maximal at $1 \mu \mathrm{M}$ ). TPA, an activator of the protein kinase $\mathrm{C}$, reduced the $\mathrm{Ca}^{2}+$ concentration required for the transmitter release. Irrespective of the presence of TPA, botulinum neurotoxins types $\mathrm{A}, \mathrm{C} 1$ and $\mathrm{D}$ inhibited the $\mathrm{Ca}^{2+}+$-evoked release of $[3 \mathrm{H}]$-labeled transmitters from the permeabilized cells with similar potency as in that from the intact cells.

These results suggest that botulinum neurotoxins inhibit the intracellular process of transmitter release streaming down from $\mathrm{Ca}^{2}+$ entry common to various neurotransmitters in central neurons.

\title{
REFERENCE
}

1. Murayama, S., Umezawa, J., Terajima, J., Syuto, B. and Kubo, S. (1987): J. Biochem., 102, 1355-1364.

\section{PLATELET AGgREgation CAUSED BY CLOSTRIDIUM PERFRINGENS ALPHA TOXIN}

\author{
Yoshio FUJII, Sadayuki OCHI, Keiko KOBAYASHI and Jun SAKURAI \\ Department of Microbiology, Faculty of Pharmaceutical Sciences, Tokushima Bunri \\ University, Yamashiro-cho, Tokushima 770, Japan
}

Clostridium perfringens alpha toxin has been thought to play an important role in gas gangrene, however, little can be said concerning the relationship between alpha toxin and the disease. Therefore, to get a clue to the role of the toxin in the pathogenesis, we have reported some pharmacological effects of the toxin such as potentiation of the contraction of the isolated rat vas deferens elicited by norepinephrine, contraction of the isolated rat aorta and aggregation of the platelets (1-3). We suggested that $\mathrm{Ca}^{2}+$ uptake and production of calmodulin$\mathrm{Ca}^{2}+$ complex are essential for the platelet aggregation caused by the toxin. 
Japan. J. Med. Sci. Biol., 41, 1988.

Alpha toxin was purified from culture supernatant fluid of $C$. perfringens type A as described previously (3). The purified preparation showed no activity of theta toxin, collagenase or hyaluronidase. Rabbit platelets were prepared by the method of Pinckard et al (4).

Alpha toxin caused simultaneous aggregation of platelets and serotonin release. Under the experimental conditions, platelet aggregation was proportional to serotonin release. Treatment of platelets with a $\mathrm{Ca}^{2}+$ entry blocker, which inhibited the platelet-aggregating activity of the toxin, resulted in inhibition of the toxin-induced serotonin release. On the other hand, cyproheptadine (serotonin inhibitor) inhibited platelet aggregation caused by the toxin in the dose-dependent manner. These data suggest that serotonin release is important in aggregation of platelet caused by the toxin.

\section{REFERENCES}

1. Sakurai, J., Nomura, S., Fujii, Y. and Oshita, Y. (1985): Toxicon, 23, 449-455.

2. Sakurai, J., Oshita, Y. and Fujii, Y. (1985): Toxicon, 23, 905-912.

3. Fujii, Y., Nomura, S., Oshita, Y. and Sakurai, J. (1986): Brit. J. Pharmacol., 88, 531-539.

4. Pinckard, R. N., Farr, R. S. and Hanahan, D. J. (1979): J. Immunol., 123, 1847-1857. 
Japan. J. Med. Sci. Biol., 41, 1988.

\title{
SOME PROPERTIES OF HOG BRAIN ACTIN ADP-RIBOSYLATED WITH COMPONENT I OF BOTULINUM C2 TOXIN
}

\author{
Iwao OHISHI and Yoshiharu MORIKAWA
}

University of Osaka Prefecture, College of Agriculture, Sakai-shi, Osaka 591

C2 toxin produced by certain strains of Clostridium botulinum types C and D is composed of nonlinked two proteins, designated components I and II. The toxin has various biological activities, which are not possessed by botulinum type A through $\mathrm{F}$ neurotoxins. We have reported that the two components of $\mathrm{C} 2$ toxin act as a molecule with dual functions, with component II as the recognizer of the receptor site on the cell surface membrane and component I as the effector in the cytoplasm. The component I of the toxin ADP-ribosylates intracellular actin of tissue-cultured cells only in the presence of component II. Thus, the various biological activities of $\mathrm{C} 2$ toxin are ascribed to the ADP-ribosylation of cytoskeletal actin with component I of the toxin. In the present study, cytoskeletal actin purified from hog brain was ADP-ribosylated with component I of C2 toxin and characterized. 
Japan. J. Med. Sci. Biol., 41, 1988.

STUDIES ON THE MECHANISM OF MEMBRANE-DAMAGING ACTION OF THE ENTEROTOXIN OF TYPE A CLOSTRIDIUM PERFRINGENS ON ARTIFICIAL LIPID BILAYER MEMBRANES

\author{
Nakaba SUGIMOTO, Kunihiro OZUTSUMI, Shigeko HARADA, \\ LEI Dian-Liang, LIU Chang-Nuan and Morihiro MATSUDA
}

Department of Tuberculosis Research I, Research Institute for Microbial Diseases, Osaka University, 3-1, Yamadaoka, Suita, Osaka 565

The enterotoxin of type A Clostridium perfringens is a simple protein with a molecular weight of about 35,000 and is a causative agent for food poisoning. By using HeLa and Vero cells, we have demonstrated the mode of cytotoxic action of the enterotoxin as follows: (1) binding of the enterotoxin to the membrane of susceptible cells, (2) formation of small "holes" in the membrane making it semipermeable to substances of molecular weights lower than about 200, (3) disturbance of membrane permeabilities to cations, i.e. efflux of potassium, magnesium and influx of sodium, (4) massive influx of extracellular calcium, (5) rapid and extraordinary increase in concentration of intracellular calcium, (6) morphological alterations of the cells, i.e. bleb-balloon formation, (7) leakage of macromolecules in cytoplasm, (8) cell death (1). Among these steps, the most important of the primary action of the enterotoxin is the step of formation of small "holes" in the membrane. Here arises a problem of whether the "holes" are composed of toxin molecule(s) alone or a mixture of the toxin and the membrane. To solve the problem, we explored the use of artificial lipid bilayer instead of cell membrane and examined by measuring ionic currents through the membrane whether the enterotoxin produces small "holes" in asolectin membrane.

Twenty-one out of 102 membranes examined in this study showed definit channel activities in their membrane current records. Characteristics of the channels formed by the enterotoxin in the asolectin membranes suggested that the formation of ionic channels by enterotoxin molecule(s) is possibly the step of formation of small "holes" itself. Large conductances of the channel in lipid membrane may explain the fact that the "holes" in the cell membrane of the enterotoxin-treated cell appeared to pass substances of molecular weight lower than 200. Bidirectional characteristic of ionic channels in lipid membrane is 
Japan. J. Med. Sci. Biol., 41, 1988.

consistent with bidirectional movement of cations through the membranes of the enterotoxin-treated cells. Extraordinarily long-lasting events of the channels in lipid membranes could explain the rapid death of the cells after treatment with the enterotoxin. Further studies on the membrane of susceptible cells by the technique of single channel recording will clarify the exact role of formation of ionic channels in the lipid bilayer by the enterotoxin in the mechanism of cytotoxic action of the enterotoxin.

\section{REFERENCE}

1. Matsuda, M., Ozutsumi, K., Iwahashi, H. and Sugimoto, N. (1986): Biochem. Biophys. Res. Commun., 141, 704-710. 